\title{
Linear Programming Technique in Fish Feed Formulation
}

\author{
Thuleswar Nath ${ }^{\# 1}$, Ashok Talukdar ${ }^{* 2}$. \\ \#Associate Professor, Department of Mechanical Engineering. \\ Jorhat Engineering College,Jorhat Assam,India
}

\begin{abstract}
Linear Programming Technique has gained grounds in warehouse problem, caterer problem, personnel problem, advertising media selection problem, crude oil refining and gasoline blending, manpower planning, allocation of aircraft to different routes, water quality management, traffic light control etc.It has also made a considerable impact on agricultural, livestock and animal husbandry research in recent years and it can also be implemented in determining fish feed compounds for fish farmers so as to improve the productivity of fishes. Fish farmers of Kamrup District of Assam use traditional method of feeding the fish but modern fish feed are formulated under complex nutrient specifications and there specifications are necessary for the growth of fishes and improving animal productivity. The development of linear programming and the use of software packages has made a great impact on the development of fish feed compounds. Good deal of work has been done in India on nutritional requirements of livestock and poultry. But studies on fish nutrition are comparatively of recent origin in Assam. Controlling feed costs is critical to the sustainability of the fish Industry. This paper has demonstrated how the application of a linear programming approach to feed formulation will lead to higher productivity in this sector as opposed to the use of relatively inefficient methods such as the trial and error method. The general model can be extended to tackle other types of feed formulation In this paper a versatile tool called 'linear programming technique' has been discussed in relation to fish feed formulation.
\end{abstract}

Keywords - Linear Programming, Fish Feed Formulation.

\section{INTRODUCTION}

Diet formulation is a process by which different ingredients are combined to provide necessary nutrition to animals at different stages of production. A diet should supply all essential nutrients and energy to maintain vital physiological functions of growth, reproduction and health of animals. Diet should be highly digestible and should have very less adverse environmental effect. A number of methods have been defined for the formulation of animal diet; square method, two by two matrix methods, simultaneous equation method, trial and error method and linear programming method to formulate least cost diet. Linear programming is widely used for this purpose. Diet formulated by linear programming is based on assumption of linearity between animal yield and nutrient ingredients included in the diet. The feed formulation model seeks the optimum combination of available feed ingredients that will satisfy the nutritional requirements of the animal at the least cost possible. The model has to satisfy a set of constraints on nutritional levels, availability restrictions, special ingredients to be included, budget or fund constraints. The generic mathematical model which is applicable to each type of ration using the available ingredients is prevalent in the industry, nutrient contents and availability of feed ingredients and their prevalent market prices. The decision variables, objective function and problem constraints were defined and a mathematical model of the feed formulation problem was developed. The technique is thus highly manoeuvrable and the nutritionist should take full advantage to investigate the varied types of alternatives for deciding on the best scheme for implementation. Improve Assam's fish industry in an integrated \& systematic manner to increase competitiveness among poor \& marginal communities / farmers dependent on fish for primary or secondary income as an effort to alleviate poverty with thrust on production. Fishing contributes a lot to the socio-economic development of Kamrup district in terms of employment, food security in a form of protein intake and also for poverty reduction in both rural and urban communities. But the industry faces a lot of challenges including high input cost, lack of infrastructure, destructive fishing methods and dominance of foreign markets. The successful completion and recommendations of this research well considered, fishermen in Kamrup district will adopt a standard mathematical model for feeding their fish.

\section{LITERATURE REVIEW}

Methods of engineering like mathematical modelling and optimization methods have been applied to some extent in the food, fishing and agricultural industry. These methods have however been applied in other purposes than for production scheduling, as to improve product processing and optimize sorting of raw material. Methods of engineering have also been used to some extent in pharmaceutics and aluminium industry. A mathematical model for the operation of dairy farms in Iceland was designed (1980) to solve the overproduction problem in agriculture and especially on dairy farms[1]. Emphasis was placed on describing the conjunction between fertilizers, concentrate feed, production and cost as well as hay quality. This was cooperation between The Agricultural University of Iceland and The Farmers Association of Iceland. The main results were that the quality of hay is crucial regarding production cost of milk. The model also showed that the most sensible way to compensate for the loss of revenues because of the contraction in production was to ensure the quality of hay. Líndal [2] designed an optimization model to evaluate how to improve the way of processing different carcasses. The model was designed to analyze how to allocate available meat at each time, based on certain time that it takes to produce each product. The model's constraints are manpower and the production time. The input is the quantity of meat processed per year. More effort has been applied to operations research within the fishing industry 
in Iceland. The ambition within the fishing industry to increase the total value of seafood has increased in recent years. Jensson[3] developed a linear programming model which maximized the profit of fish processing firms. The goal was to develop a decision support system for a production manager in fish processing firms, regarding an overall decision making in the production plant, as staff scheduling and what to produce at each time. The model was tested in a fish processing plant in Reykjavík and was found to be very useful for the production managers. Amodel was developed (1999) by Gunnarsson and Jensson[4] to help with decision making for the most profitable classification of fish. The model also calculates the highest possible product value of available fishing in process at each time. The model uses mathematical optimization methods to maximize product value of capelin, herring and shrimps based on their size distribution. Margeirsson et al. collected data from 2002 to 2006 on fillet yield, gaping and parasites [5]. Runarsson (2006) utilized this data set to develop a linear optimization model that maximized the profit of an Icelandic company in the field of fish processing [6]. The objective of the project was to analyse the data and show how to utilize the data to increase productivity and profit of companies within the fishing industry.

\section{METHODOLOGY}

The data was obtained from the field through questionnaires and were administered through interviews due to the fact that some of the respondents could not read and write. The analysis of the data was done using linear programming. Linear programming is a considerable field of optimization for several reasons. Many practical problems in operation research can be expressed as LP problems. Certain special cases of LP, such as network flow problems and multicommodity flow problems are considered important enough to have generated much research on specialized algorithms for their solution. A number of algorithms for other types of optimization problems work by solving LP problems as subproblems. Historically, ideas from LP have inspired many of the central concepts of optimization theory,such as duality, decomposition, and the importance of convexity and its generalizations. Although the modern management issues are ever-changing, most companies would like to maximize profits or minimize costs with limited resources. Therefore, many issues can be characterized as LP problems. One of the important assumptions made in the formulation of the linear programming problem is that of linearity. The expression to be optimized and the inequalities are assumed to be linear functions of the variables. The linear model employs an assumption of fixed prices and constant returns to scale. Under the linear model the total protein content for example, of the feed mixture is assumed to be the sum of the protein contents of the individual ingredients whatever the proportion of the ingredients in the mixture be. Thus no interaction is envisaged. Another assumption is that the coefficients such as the ones used for conversion of feed ingredients into their nutrient equivalents and also the prices of ingredients are known with certainty. These assumptions may be unrealistic for some situations and more sophisticated techniques like non-linear and stochastic programming could be thought of.
But within certain limits, for the problem of getting optimum feed mixtures the assumptions can be taken to be fairly reasonable.

\section{DATA COLLECTION AND ANALYSIS}

Data was collected with respect to nutrient requirement of Principal Carp, market price of various ingredients prevalent in Kamrup district, analysis of data collected, thus formulation of the model which will enable Fish Farmers of Kamrup District to compare a wide range of feedstuffs to determine which will blend together to provide the desired nutrient levels at the lowest possible cost without bias toward any ingredient.

Data collection of nutrient contents of different ingredients, their respective market prices and minimum nutrients requirement of Common Carp.

TABLE1

NUTRIENTS CONTENTS OF INGREDIENT-GROUNDNUT CAKE

\begin{tabular}{|c|c|}
\hline Protein \% & 38 \\
\hline Lipid \% & 9.01 \\
\hline Carbohydrate \% & 27.99 \\
\hline Calcium \% & 0.25 \\
\hline Phosphorous \% & 0.65 \\
\hline
\end{tabular}

Source: Principles of Animal Nutrition and Feed Technology by D.V.Reddy and Fish and Fisheries of India by V.G.Jhingran

TABLE 2

NUTRIENTS CONTENTS OF INGREDIENT-SOYBEAN CAKE

\begin{tabular}{|c|c|}
\hline Protein \% & 37.03 \\
\hline Lipid \% & 7.1 \\
\hline Carbohydrate \% & 28.03 \\
\hline Calcium \% & - \\
\hline Phosphorous \% & - \\
\hline
\end{tabular}

Source: Principles of Animal Nutrition and Feed Technology by D.V.Reddy and Fish and Fisheries of India by V.G.Jhingran

TABLE 3

NUTRIENTS CONTENTS OF INGREDIENT-RICE BRAN

\begin{tabular}{|c|c|}
\hline Protein \% & 13.24 \\
\hline Lipid \% & 4.3 \\
\hline Carbohydrate \% & 42.65 \\
\hline Calcium \% & 0.06 \\
\hline Phosphorous \% & 1.50 \\
\hline
\end{tabular}

Source: Principles of Animal Nutrition and Feed Technology by D.V.Reddy and Fish and Fisheries of India by V.G.Jhingran 
TABLE 4

NUTRIENTS CONTENTS OF INGREDIENT-WHEAT BRAN

\begin{tabular}{|c|c|}
\hline Protein \% & 13.9 \\
\hline Lipid \% & 4.2 \\
\hline Carbohydrate \% & 55.6 \\
\hline Calcium \% & 0.2 \\
\hline Phosphorous \% & 1 \\
\hline
\end{tabular}

Source: Principles of Animal Nutrition and Feed

Technology by D.V.Reddy and Fish and Fisheries of India by V.G.Jhingran

TABLE 5

NUTRIENTS CONTENTS OF INGREDIENT-FISH MEAL

\begin{tabular}{|c|c|}
\hline Protein \% & 55 \\
\hline Lipid \% & 1.8 \\
\hline Carbohydrate \% & - \\
\hline Calcium \% & 4.5 \\
\hline Phosphorous \% & 2.5 \\
\hline
\end{tabular}

Source: Principles of Animal Nutrition and Feed

Technology by D.V.Reddy and Fish and Fisheries of India by V.G.Jhingran

TABLE 6

NUTRIENTS CONTENTS OF INGREDIENT-BEWER WASTE

\begin{tabular}{|c|c|}
\hline Protein \% & 22.8 \\
\hline Lipid \% & 17.8 \\
\hline Carbohydrate \% & 46.4 \\
\hline Calcium \% & - \\
\hline Phosphorous \% & - \\
\hline
\end{tabular}

Source: Principles of Animal Nutrition and Feed Technology by D.V.Reddy and Fish and Fisheries of India by V.G.Jhingran

TABLE 7

NUTRIENTS CONTENTS OF INGREDIENT -TIL CAKE

\begin{tabular}{|c|c|}
\hline Protein $\%$ & 45 \\
\hline Lipid $\%$ & 12 \\
\hline Carbohydrate $\%$ & 24.5 \\
\hline Calcium $\%$ & 0.5 \\
\hline Phosphorous \% & 1 \\
\hline
\end{tabular}

Source: Principles of Animal Nutrition and Feed Technology by D.V.Reddy and Fish and Fisheries of India by V.G.Jhingran

TABLE 8:

MARKET PRICE OF INGREDIENTS (RS./KG)

\begin{tabular}{|c|c|}
\hline Groundnut cake & 24 \\
\hline Fish Meal & 25 \\
\hline Soybean Meal & 34.8 \\
\hline Brewer Waste & 12 \\
\hline Wheat Bran & 10 \\
\hline Til Cake & 15 \\
\hline Rice Bran & 6 \\
\hline
\end{tabular}

Source : Market Survey (Price related to Kamrup district of Assam)
TABLE 9

MINIMUM NUTRIENT CONTENTS REQUIREMENT OF PRINCIPAL CARP.

\begin{tabular}{|c|c|}
\hline Protein \% & 38 \\
\hline Lipid \% & 6 \\
\hline Carbohydrate \% & 26 \\
\hline Calcium \% & 1 \\
\hline Phosphorous \% & 0.6 \\
\hline
\end{tabular}

Source: Principles of Animal Nutrition and Feed Technology by D.V.Reddy and Fish and Fisheries of India by V.G.Jhingran

Formulation of LP Model for Principal Carp.

Consider formulation of a feed mixture with ingredients shown in the following table and subject to minimum nutrient contents. The quantity of the mixture to be prepared is $100 \mathrm{~kg}$.

Let (x1), (X2), (X3), ( x 4 ), ( X5), ( X6), ( X7) and( X8) be the respective quantities in $\mathrm{kg}$ of groundnut cake, soyabean cake, rice-bran, wheat bran, fish meal, brewer waste ,til cake required for the mixture. The minimum-cost linear programming model can be written as.

$\min : 24 * \mathrm{X} 1+18 * \mathrm{X} 2+6 * \mathrm{X} 3+10 * \mathrm{X} 4+25 * \mathrm{X} 5+12 * \mathrm{X} 6+$ $15 * \mathrm{X} 7 ; ; \ldots . .($ cost function $)$

Constraint $1: 0.38 * \mathrm{X} 1+0.37 * \mathrm{X} 2+0.1324 * \mathrm{X} 3+0.139 * \mathrm{X} 4+$ $0.55^{*} \mathrm{X} 5+0.228^{*} \mathrm{X} 6+0.45^{*} \mathrm{X} 7>=38 ; \ldots \ldots . .$. (Protein requirement)

Constraint 2: $0.09 * \mathrm{X} 1+0.07 * \mathrm{X} 2+0.043 * \mathrm{X} 3+0.042 * \mathrm{X} 4+$ $0.018 * \mathrm{X} 5+0.178 * \mathrm{X} 6+0.12 * \mathrm{X} 7>=6 ; \ldots \ldots \ldots .($ Lipid requirement)

Constraint3: $0.27 * \mathrm{X} 1+0.28 * \mathrm{X} 2+0.42 * \mathrm{X} 3+0.556 * \mathrm{X} 4+$ $0.462 * \mathrm{X} 6+0.245 * \mathrm{X} 7>=26 ; \ldots \ldots \ldots$. (Carbohydrate requirement)

Constraint4: $0.0025 * \mathrm{X} 1+0.0006 * \mathrm{X} 3+0.002 * \mathrm{X} 4+0.045 * \mathrm{X} 5$

$+0.005 * \mathrm{X} 7>=1 ; \ldots \ldots \ldots . .($ calcium requirement $)$

Constraint5: $0.0065 * \mathrm{X} 1+0.015 * \mathrm{X} 3+0.01 * \mathrm{X} 4+0.025 * \mathrm{X} 5$

$+0.01 * \mathrm{X} 7>=0.6 ; \ldots \ldots \ldots .($ Phosphorous requirement $)$

Constraint6: $\mathrm{X} 1+\mathrm{X} 2+\mathrm{X} 3+\mathrm{X} 4+\mathrm{X} 5+\mathrm{X} 6+\mathrm{X} 7$

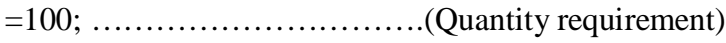


TABLE 10

SOLUTION OF THE MINIMIZATION MODEL USING LIPS SOFTWARE

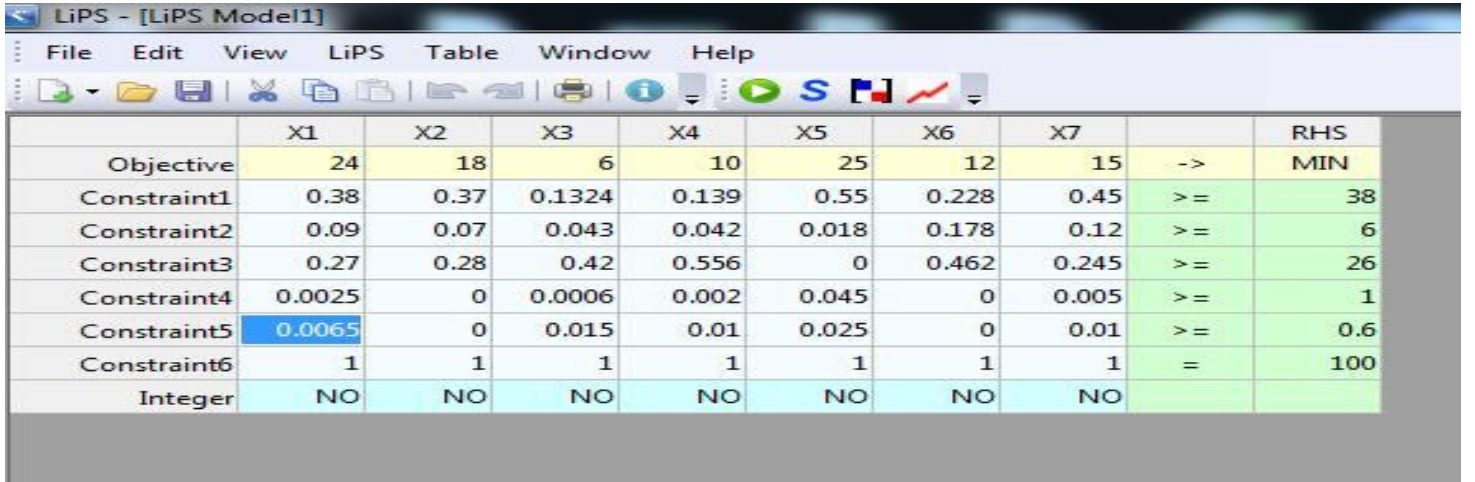

\section{Result of the minimization model for Principal Carp.}

Therefore it is found that $22.98 \mathrm{~kg}$ of rice bran,3.96 kg of wheat bran, $15.32 \mathrm{~kg}$ of fish meal and $57.72 \mathrm{~kg}$ of til cake are the required quantities for the mixture of $100 \mathrm{~kg}$ which satisfies the Minimum Nutrient Contents Requirement of Principal Carp and also minimise the cost where the optimal cost of the $100 \mathrm{~kg}$ mixture is found to be Rs. 1426.57

\section{CONCLUSIONS}

It is imperative for fish feed farmers to search for alternative feedstuffs keeping in mind the high prices of fish feed ingredients and non availability without affecting the quality of feed and fish productivity. Availability of quality feed at a reasonable cost is a key to successful fish farming operation and linear programming technique is one of the most important techniques to allocate the available feedstuffs in a least cost ration formulation. The optimal solution of the linear programming model gives reduction in feed formulation costs compared to the existing method on the farm. Fish feed cost represents over $70 \%$ of the total cost of production; consequently efficient feed formulation practice is required for a sustainable fish industry. Many Assamese fish farmers, however, employ inefficient methods like rule of thumb, experiences, and intuition to handle feed formulation problem. The aim of this study was to develop an optimization feed formulation model, using locally available feed ingredients, for the Assam's fish farmers. Relevant literature was consulted to gather information on the practices Application of the linear programming technique in the field of fish feed formulation ideates the computation of a minimum-cost feed mixture meeting several specifications. . There is wide scope for research in this field in Assam. As a result of this work, more efficient rations could be produced; using nutrient restrictions and nutrient composition data more specifically related to Assam conditions and feed ingredients.

\section{ACKNOWLEDGMENT}

The Author wishes to acknowledge T. Jacob and R.Paul Raj of Central Marine Fisheries Research Institute who have originally proposed the idea of Linear programming technique for the fish farmers of India.

\section{REFERENCES}

[1] Gunnar Sigurdsson et. al. Reiknilikan af mjolkurframleidslu kuabua. Cooperation between The Agricultural University of Iceland and The Farmers Associaton of Iceland, 1980.

[2] Johann Haukur Kristinn Lindal. Aðgerðagreining við vinnslu á dilkakjöti. Master thesis in the University of Iceland in the faculty of industrial engineering, 2005.

[3] Páll Jensson. Daily production planning in fish processing firms. European Journal of Operational Research, 36, 1988.

[4] Pall Jensson and Halfdan Gunnarsson. Hámörkun afurðaverðmætis loðnu, rækju og síldar. A Report to RANNIS, Reykjavik, 1999.

[5] Sveinn Margeirsson. Processing forecast of cod. Decision making in the cod industry based on recording and analysis of value chain data. Ph.D. Thesis, faculty of Engineering, University of Iceland, 2008.

[6] Runolfur Guðmundsson. Ákvarðanataka og bestun í sjávarútvegi. M.Sc. Thesis, faculty of Engineering, University of Iceland, 2006.

[7] Dantzig, G.B.1963. 'Linear programming and extension', Princeton University Press and the Rand Corporation.

[8] Al-Deseit, Bassam.2009. 'Least cost broiler ration formulation using linear programming technique', Journal of Animal and Veterinary Advances 8(7):1274-1278.

[9] Black, J.R. and Hlubik, J.1980. 'Basics of computerized linear programs for ration formulation', Journal of Dairy Science, 63:1366-77. 